\title{
A comprehensive investigation of TPACK within pre-service teachers' ICT profiles: Mind the gap!
}

\author{
Jo Tondeur \\ Vrije Universiteit Brussel

\section{Ronny Scherer} \\ University of Oslo \\ Fazilat Siddiq \\ Nordic Institute for Studies in Innovation, Research and Education, Oslo \\ Evrim Baran \\ Middle East Technical University, Ankara
}

\begin{abstract}
This study aims to identify profiles of pre-service teachers in order to explore their readiness to integrate technology in education. The assumption is that pre-service teacher characteristics such as technological pedagogical content knowledge (TPACK), go together with the influence of their teacher training. Specifically, this study examines whether preservice teachers can be clustered on the basis of their TPACK, a typical set of ICT-related characteristics (e.g., general ICT attitudes, attitudes towards ICT in education, ease of use, ICT self-efficacy), and the perceived support at their training institution to adequately integrate ICT in education. Data were collected from a sample of 688 last-year pre-service teachers in 18 teacher training institutions in Flanders (the Dutch-speaking part of Belgium). Using correlational and latent profile analysis, the results suggest that: (1) two profiles can be distinguished, (2) TPACK and other individual ICT-related characteristics are positively correlated, and (3) pre-service teachers in a profile with strong TPACK, attitudes, and self-efficacy scores also report high scores on the support they perceive at their teacher training institution. Implications for the role of teacher training institutions are discussed with a specific focus on how to close the gap between the two identified profiles.
\end{abstract}

\section{Introduction}

Today, school teachers are dealing with a new generation of students who are growing up with new technologies as omnipresent tools. The changes have been faster than could have been imagined two or three decades ago (Spector, 2010). But increasing access to technology does not seem to be enough to lead to effective use of technology in education (Tondeur, van Braak, Siddiq, \& Scherer, 2016). Teachers play a key role in enhancing student learning with technology-enhanced classroom practices. Consequently, preparing future teachers to integrate technology in their educational practice is a challenge that teacher training institutions (TTI) are increasingly confronted with (Liu, 2016; OttenbreitLeftwich, Glazewski, Newby, \& Etmer, 2010). To train pre-service teachers, TTIs need to help them bridge the gap between technology, pedagogy, and content knowledge (TPACK). Koehler and Mishra (2009) argue that for technology integration to occur in education, teachers must be competent in these three forms of knowledge, but more importantly, they must be able to integrate all three types of knowledge (Sang, Tondeur, \& Chai, 2014; Schmidt et al., 2009). TPACK emphasises the importance of preparing pre-service teachers to make sensible choices in their uses of technology when teaching particular content to a specific target group.

The need to better align pre-service teachers' preparation for the integration of technology with pedagogical issues and curriculum has been noted by many researchers recently (e.g., Agyei \& Voogt, 2014, 2015; Ottenbreit-Leftwich et al., 2010). But preparing student teachers for TPACK is a complex process (Aslan \& Zhu, 2016; Tondeur et al., 2012). Some pre-service teachers are intrinsically motivated to use ICT in educational practice, while others do not share this affinity. For this reason, many researchers have centred on critical individual characteristics associated with TPACK, such as pre-service 
teachers' attitudes (e.g., Holland \& Piper, 2016), ease of use (e.g., Teo \& Milutinovic, 2015), and their self-efficacy (e.g., Abbitt, 2011; Siddiq, Scherer, \& Tondeur, 2016). But a mere focus on pre-service teachers' characteristics could lead to individual blame rather than system blame when focusing on explaining variables related to TPACK. Therefore, research should also stress the role of pre-service training (Mouza, Karchmer-Klein, Nandakumar, Ozden, \& Hull, 2014). TTIs differ with respect to performance levels, innovation capacity, and contextual characteristics (Tondeur, Pareja Roblin, van Braak, Fisser, \& Voogt, 2013). This implies that educational improvement or innovation efforts should consider to a large extent the power of site or place (Fullan, 2001).

This study aims to determine which pre-service teacher characteristics are connected to the perceived support from their TTIs to prepare them for educational ICT use. Specifically, the study examines whether pre-service teachers can be clustered on the basis of a typical set of: (1) individual characteristics such as TPACK, their attitudes towards ICT (in education), their ICT self-efficacy, and ease of use; and (2) the support pre-service teachers perceive from their TTIs with respect to technology integration in education. Before presenting the results of the empirical study, we first elaborate on the individual preservice teachers' characteristics related to TPACK. We subsequently describe the strategies TTIs can adopt to prepare pre-service teachers for TPACK and how likely they are to influence the ICT profile of pre-service teachers. In the conclusion, the implications for practice and future research are discussed.

\section{Background}

\section{TPACK and teacher education}

Despite large expenditures, increased access and almost universal use by school-age children, several observers have questioned the extent to which technology is affecting teaching and learning (Spector, 2010). Effectively integrating technology into learning systems is much more complex than providing computers and securing a connection to the Internet. Computers, digital whiteboards, or tablets are merely tools; no technology can compensate for inadequate practices (Ertmer, 2005; Tondeur, van Braak, Ertmer, \& Ottenbreit-Leftwich, 2016). Critical choices have to be made in terms of the relationship between ICT use and educational objectives. To address this challenge, many TTIs have included introductory technology courses in their curriculum (Polly, Mims, Shephard, \& Inan, 2010; Schmidt et al., 2009). These courses aim to equip pre-service teachers with a set of basic competencies they can transfer to their future classroom practice. However, beginning teachers often feel not prepared to effectively use technology in their classrooms (e.g., Sang, Valcke, van Braak, \& Tondeur, 2010). At the same time, the evidence reveals that beginning teachers use technological applications mainly for structured learning approaches, while few created opportunities for student-centred technology use (Ottenbreit-Leftwich, Ertmer, \& Tondeur, 2015; Tondeur, Pareja Roblin, van Braak, Voogt, \& Prestridge, 2017).

The need to better align pre-service teachers' preparation in the integration of technology with pedagogical issues and curriculum integration has been noted by many researchers recently (e.g., Angeli \& Valenides, 2009; Voogt, Fisser, Pareja, Tondeur, \& van Braak, 2013). Research reveals that this has resulted in strategies by TTIs (e.g., using teacher educators as role models, learning technology by design, scaffolding authentic technology experiences) to develop pre-service teachers' TPACK (Tondeur, van Braak, Ertmer et al., 2016). TTIs have also engaged in conditions necessary to implement such strategies (e.g., technology planning and leadership, co-operation within and between institutions, training staff [Polly et al., 2010]).

Clearly, there are different strategies for the content and delivery methods to prepare pre-service teachers for technology use (e.g., Kay, 2006; Mouza et al., 2014). Still, the question remains how TTIs can get a comprehensive overview of effective strategies. In this respect, Tondeur et al. (2012) reviewed 19 qualitative studies in order to develop an SQD-model (synthesis of qualitative evidence) on which content and delivery methods best prepare pre-service teachers to integrate technology into their future classrooms (Figure 1). 


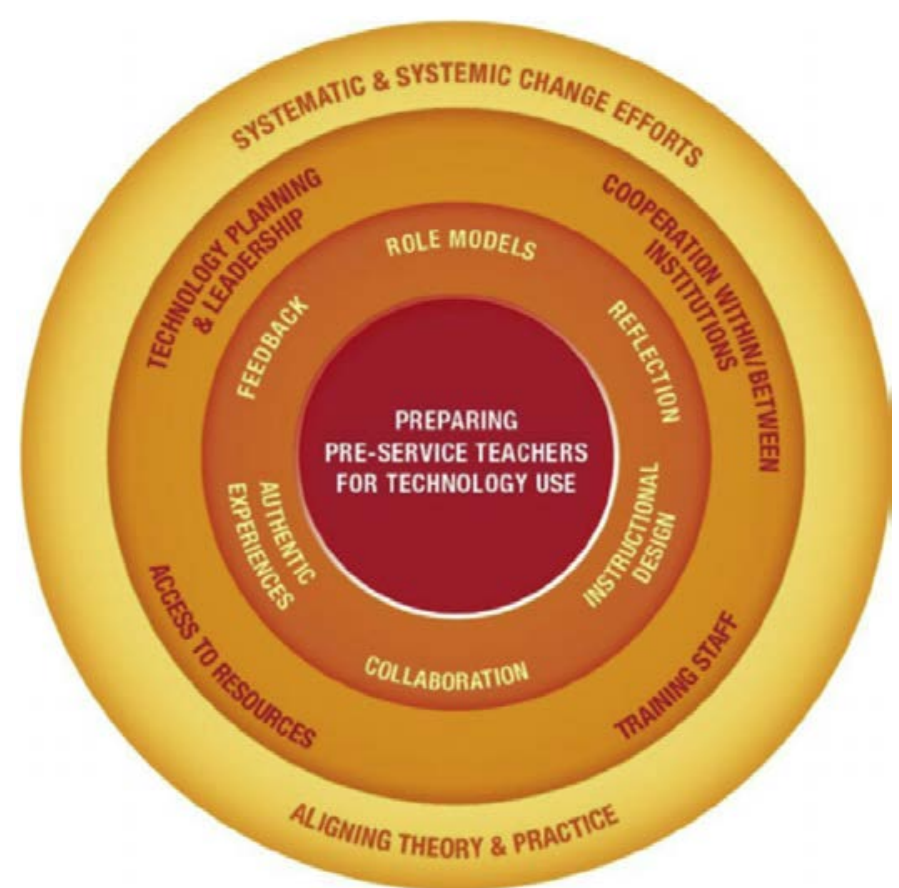

Figure 1. SQD-model to prepare pre-service teachers for technology use (Tondeur et al., 2012)

According to the findings of this review, 12 key themes need to be in place in the teachers' education programs to prepare future teachers for technology integration. The two outer circles in the SQD-model include the conditions necessary at the institutional level such as technology planning and leadership, training staff, access to resources, cooperation within and between the institutions. The two inner circles include micro-level strategies such as using teacher educators as role models, and scaffolding authentic technology experiences. These six strategies at the micro-level were examined in this study.

The first strategy involves teacher educators acting as role models. Although this has proven to be an important motivator for future technology integration in the classroom (Kaufman, 2015), simply having pre-service teachers watch examples of technological applications is helpful but not sufficient. Because pre-service teachers should also be able to interpret these examples in a specific educational context, the second strategy consists of discussing and reflecting upon successful uses of technology. This might help them to see the utility, value, and feasibility of using a particular technology and/or teaching strategy (cf. Mouza et al., 2014), hence furthering their ability to differentiate between action and purpose and enabling deeper and more critical thinking about technology integration.

Research also suggests that providing the opportunity to learn about technology integration by redesigning curriculum materials (strategy 3) can also be a promising strategy (Lee \& Lee, 2014). In several studies, pre-service teachers stated that technology integration required additional planning and preparation because they had no prior knowledge about or experience with the design of ICT-supported learning activities (e.g., Polly et al., 2010). Many studies have demonstrated that group work (strategy 4) might mitigate these feelings of insecurity when teachers need to design technology-related curriculum materials (Tearle \& Golder, 2008). As a fifth strategy, pre-service teachers may also apply their knowledge of educational technology in authentic settings (Sang et al., 2012; Valtonen et al., 2015). Finally, the sixth strategy involves on-going and process-oriented feedback, which has been proven to be beneficial for pre-service teachers' abilities to use technology in the classroom (Banas \& York, 2014). In the current study, we aim at delineating profiles on the basis of pre-service teachers' ICT-related attitudes, their TPACK, and the support they perceive provided by their institution (SQD). 


\section{Pre-service teachers' ICT profiles}

Niess (2015) found that TPACK is highly personal. To understand pre-service teachers' TPACK, we therefore need to study several individually and perception-based characteristics of their ICT profiles. In this section, we review the literature grounds for the importance of pre-service teachers' characteristics that are related to educational ICT use and how this can be associated to their TPACK. Yet, this list of factors cannot reflect the full complexity of characteristics. The knowledge base presented in this paper is by no means definitive or exhaustive. Understanding one element leads to the necessity to understand the foundation on which that element rests, which in turn can lead to the discovery of other significant elements.

Clearly, attitudes towards technology influence whether (pre-service) teachers integrate ICT into their classroom (Scherer, Siddiq, \& Teo, 2015; Teo, 2008). Different authors found that among the factors that affect TPACK and the successful use of ICT in the classroom, teachers' attitudes towards ICT play a key role (Sang et al., 2012). Research (Pynoo et al., 2011; Siddiq et al., 2016) also supported that educational ICT use was strongly affected by specific attitudes, such as attitudes toward ICT in education and ease of use. Therefore, a scale is used in this study that includes a broad spectrum of dimensions such as usefulness, ease of use, interest, and pleasure. Consequently, the current study can be situated in the tradition of the technology acceptance model (TAM). TAM posits that pre-service teachers' acceptance is determined by two key dimensions, namely perceived usefulness and ease of use (cf. Venkatesh et al., 2013). These dimensions are included in the attitudes scale used in this study.

Several studies show that ICT self-efficacy is also positively correlated with an individual's willingness to choose and participate in ICT-related activities. Self-efficacy regarding technology refers to a person's perceptions of and capabilities to apply computers (Compeau \& Higgins, 1995). Pre-service teachers with higher levels of ICT self-efficacy use ICT more often (Kavanoz, Yuksel, \& Ozcan, 2015). Research confirmed positive relations between pre-service teachers' TPACK and their self-efficacy in integrating ICT (Semiz \& Ince, 2012). In the current study, we focus on pre-service teachers' self-efficacy to manage ICT for their own teaching purposes (see Tondeur et al., 2017). In the Tondeur et al. (2017) study a reasonable positive correlation is found between pre-service teachers' self-efficacy to use ICT as a supportive tool (e.g., to select or design educational ICT applications or the use of ICT to track the learning process of pupils) and their efficacy to use ICT in the classroom (e.g., support pupils to present information by means of ICT or to motivate pupils to use ICT in a positive way). This relationship between both types of ICT competencies can also be found in other studies (e.g., Sang et al., 2010) that the supportive use of ICT is the most significant predictor of actual classroom ICT use.

\section{Research objectives}

In the literature, the question is repeatedly put forward as to what variables are associated with pre-service teachers' TPACK. In this respect, the process of TPACK development is dynamic and involves interacting factors. A number of studies have focused on either the role of TTIs or the pre-service teachers' individual characteristics. Even though, it has been assumed that these are positively related, no study included both in the profile of pre-service teachers. This person-centred approach is rooted in the holistic-interactionistic research paradigm (Bergman \& Magnusson, 1997; Bergman, von Eye, \& Magnusson, 2006). In this paradigm, variables dynamically interact with person characteristics and are therefore considered to be an integral part of the overall functioning of an individual (Bergman \& Wångby, 2014; Magnusson, 1998). In contrast, the variable-centred approach - an approach that is most commonly employed in psychological research - typically addresses variables and their relationship to and/or predictive ability for the outcome of a study (Laursen \& Hoff, 2006). Hence, the focus is on the structure of the variables across persons rather than the response patterns within the persons (Marsh, Lüdtke, Trautwein, \& Morin, 2009). Moreover, this approach is based on the understanding that the variable-outcome relation is the same across the population - this is, according to Laursen and Hoff (2006) seldom the case. On the contrary, the person-centred approach is based on population heterogeneity and warrants examination of the patterns and relationships among the variables at the level of the individual allowing for a more holistic view of the persons under study (Magnusson, 1998). In this study, we focus on the relationship between pre-service teachers' TPACK, their individual characteristics, and perceptions on the support provided by TTIs. Furthermore, we aim at delineating profiles based on pre-service teachers' ICT-related attitudes, the support they perceive provided by their institution (SQD) 
and their TPACK. In this respect, we distinguish between technological knowledge (TK) as a purely technological dimension in TPACK, and the technology and pedagogical dimensions, TPK, TCK, and TPCK.

\section{Research method}

\section{Sample and instruments}

A survey was developed to explore pre-service teachers' characteristics (including TPACK) and the support pre-service teachers receive in their TTIs (the strategies included in the SQD-model). The survey was conducted among $N=688$ pre-service teachers from 18 teacher training institutions in Flanders (Belgium) in their final year of education. All respondents received an email invitation to fill in the survey; participation was completely voluntary. $73.8 \%$ of the respondents were females. The average age was 25.1 years ( $S D=7.7$ years). $57.7 \%$ of the pre-service teachers had obtained a Bachelor's degree in higher education and $42.3 \%$ had obtained a specific teacher training degree from universities, colleges, or centres for adult learning.

\section{TPACK}

The measurement of the TPACK technology-dimensions (TCK, TPK, TPCK, and TK) was based on the adapted Dutch version of Schmidt et al.’s (2009) TPACK self-report scale (Fisser, Voogt, Tondeur, \& van Braak, 2015). Teacher students was asked to indicate the extent to which they agreed with a number of statements that referred to the technology-dimensions ( $0=$ I completely disagree, $4=$ I completely agree $)$. This new instrument revealed a general TPACK (TPCK, TPK, and TCK) and a specific TK factor (Scherer, Siddiq, \& Tondeur, In press; see Appendix A). The general TPACK factor was measured by 14 items that tapped TPCK, TPK, and TCK (Cronbach's $\alpha=.94$ ), whereas the TK scale was measured by 7 items (Cronbach's $\alpha=.89$ ).

\section{Attitudes towards ICT (in education)}

The first instrument employed to measure pre-service teachers' attitudes is the general attitudes toward ICT scale (Cronbach's $\alpha=.82$ ), a 5-item scale developed by Evers, Sinnaeve, Clarebout, van Braak, and Elen (2009). It includes items relating to interest (e.g., "I want to know more about computers"), pleasure (e.g., "I like to talk about computers to others"), and usefulness (e.g., "The use of a computer is useful to me"). The ease of use scale (Cronbach's $\alpha=.89$ ) contains three items (e.g., "I feel comfortable when I use computers”). The attitudes toward ICT in education scale (Evers et al., 2009) measures students' attitudes toward the effects of adopting computers in education including the same spectrum of dimensions: interest, ease of use, pleasure and usefulness. The eight items on pre-service teachers' self-efficacy (Cronbach's $\alpha=.89$ ) measure the degree to which pre-service teachers feel competent to use ICT as a supportive tool to strengthen their instructional practice (Tondeur et a., 2017), for example, "select ICTapplications in view of a specific educational setting" or "design a learning environment with the available infrastructure”. Respondents were asked to rate each statement of all on a 5-point Likert scale, anchored between: 0 - strongly disagree and 5 - strongly agree.

\section{SQD-scale}

The SQD-scale used in this study was constructed around the six significant domains of the inner circle (e.g., the micro-level) of the SQD-model (Tondeur, van Braak, Siddiq et al., 2016), a model based on the synthesis of qualitative evidence (Tondeur et al., 2012 [Figure 1]): (1) using teacher educators as role models, (2) reflecting on the role of technology in education, (3) learning how to use technology by design, (4) collaboration with peers, (5) scaffolding authentic technology experiences, and (6) providing continuous feedback (22 items, Cronbach's $\alpha=.97$ ). Respondents were asked to rate each statement of all on a 5-point Likert scale, anchored between: 0 - strongly disagree and 5 - strongly agree.

\section{Latent profile analysis (LPA)}

In order to identify latent profiles in pre-service teachers' data, we conducted latent profile analyses to our cross-sectional data set. This probabilistic approach is person-centred, as it creates a categorical latent variable which represents pre-service teachers' unobservable (i.e., probabilistic) membership in a profile (Berlin, Williams, \& Parra, 2014; Masyn, 2013); in fact, LPA results in the most likely profile membership for individuals (Morin, Morizot, Boudrias, \& Madore, 2011). Marsh et al. (2009) recognised 
that LPA represents a flexible, model-based approach to group individuals in homogeneous profiles, which has several advantages over cluster analysis (refer to Marsh et al., 2009, for a detailed discussion of these advantages).

LPA is commonly employed as a series of models with varying numbers of profiles. These models are subsequently compared according to the changes in relative fit statistics such as information criteria (Nylund, Asparouhov, \& Muthén, 2007). More specifically, LPA models with lower information criteria (i.e., Akaike's Information Criterion [AIC], Bayesian Information Criterion [BIC], and the sample-size adjusted BIC [aBIC]), are generally preferred (Marsh et al., 2009). In addition to comparing the values of information criteria, likelihood-ration tests (LRTs) provide another possibility to disentangle which model fits best. As many other LRTs, the Vuong-Lo-Mendell-Rubin (VLMR) and Lo-Mendell-Rubin (LMR) likelihood ratio tests compare the differences in models' deviances (i.e., deviance $=-2 *$ Log-Likelihood value $[\operatorname{LogL}]$ ) on the basis of a $\chi^{2}$ statistic. In the case where an LPA model with $k-1$ profiles is compared to an LPA model with $k$ profiles, a significant outcome $(p<.05)$ of either tests indicates that the model with $k$ profiles is preferred (Lo, Mendell, \& Rubin, 2001; Nylund et al., 2007). Both the LRTs and the information criteria can be used to decide on the best-fitting model and therefore the number of profiles.

Besides these two sources of information, researchers can also examine the uncertainty with which individuals are assigned to the profiles in an LPA model. This uncertainty is referred to as entropy. In the statistical software Mplus, however, estimates entropy as the certainty of classification. Hence, high entropies - as obtained from Mplus - indicate a high degree of certainty in the classification of individuals (Morin et al., 2011). Entropies larger than .60 can be regarded as substantial (Pastor, Barron, Miller, \& Davis, 2007), and entropies that exceed .70 indicate a good classification accuracy (Reinecke, 2006). Generally, entropies can be improved if predictors of profile membership (i.e., further variables that are not used to form the profiles) are included in the analyses (Masyn, 2013). Tein, Coxe, and Cham (2013), however, warned that entropies may be misleading when making a decision on the number of profiles and therefore the final LPA model. Hence, the proposed guidelines cannot serve as strict rules in order to make a pass-fail decision for any LPA model. Instead, Marsh et al. (2009) and Morin et al. (2011) argued that this decision should also be based on the interpretability of the latent profiles. In fact, if profiles cannot be distinguished well, an LPA model with fewer profiles might be preferred.

\section{Estimation procedure and missing data}

The latent profile analyses were based on robust maximum likelihood estimation (MLR), an estimation procedure that corrects for potential deviations from the normality of variables. The means of all scales were used to disentangle the profiles. In the current data set, 3.3\% of the variables were missing due to participants' non-responses, and we used the full-information-maximum-likelihood procedure in order to handle them under the assumption that they occurred randomly (Enders, 2010). All analyses were employed in Mplus 7.3 (Muthén \& Muthén, 1998-2015).

\section{Results}

\section{Descriptive statistics and correlations among variables}

Table 1 summarises the bivariate correlations between all variables under investigation. The correlations between the variables measuring pre-service teachers' ICT characteristics vary between $r=.35$ and $r=$ .77. Both ICT use $(r=.12, p<.001)$ and ICT competencies $(r=.09, p<.01)$ are significantly related to TPACK. Furthermore, the results suggest significant inter-relationships between TK and TPACK $(r=.77$, $p<.001)$. Table 1 indicates that the ICT-related variables ICT attitudes, attitudes towards the use of ICT in education, ease of use, and ICT self-efficacy are closely related. The results also suggest that there is a significant association between the individual characteristics and SQD. 
Table 1

Means, standard deviations, and correlations for the total sample $(N=688)$

\begin{tabular}{lllllllll}
\hline Variable & $M$ & $S D$ & 1 & 2 & 3 & 4 & 5 & 6 \\
\hline 1. SDQ & 2.70 & 1.01 & & & & & & \\
2. General ICT attitudes & 3.48 & 0.81 & $.27^{* *}$ & & & & & \\
3. Attitudes toward the & 4.01 & 0.79 & $.16^{* *}$ & $.59^{* *}$ & & & & \\
educational ICT use & & & & & & & \\
4. Ease of ICT use & 3.37 & 0.94 & $.22^{* *}$ & $.61^{* *}$ & $.48^{* *}$ & & & \\
5. ICT self-efficacy & 3.36 & 0.76 & $.43^{* *}$ & $.42^{* *}$ & $.35^{* *}$ & $.46^{* *}$ & & \\
6. TPACK & 2.64 & 0.59 & $.53^{* *}$ & $.51^{* *}$ & $.40^{* *}$ & $.49^{* *}$ & $.65^{* *}$ & \\
7. Technological & 2.51 & 0.72 & $.41^{* *}$ & $.60^{* *}$ & $.36^{* *}$ & $.60^{* *}$ & $.61^{* *}$ & $.77^{* *}$ \\
knowledge (TK) & & & & & & &
\end{tabular}

Note. The correlations reported here are estimated on the basis of the mean scale scores.

\# This variable contained the TPACK dimensions TPCK, TPK, and TCK. $M$ and SD are used to represent mean and standard deviation, respectively. $* p<.05 ; * * p<.01$.

The results give a first impression of the relationship among the research variables. Yet, these correlation measures do not provide information about how pre-service teachers might be clustered in different profiles.

\section{Latent profile analysis}

Decision on the number of profiles

We performed latent profile analyses with varying numbers of profiles and used pre-service teachers' age (in years) and gender ( $1=$ male, $2=$ female) as covariates. Table 2 details the resultant information criteria, entropies, and the outcomes of the likelihood ratio tests. As shown in this table, an increasing number of potential profiles is associated with a decrease in the information criteria (i.e., AIC, BIC, and aBIC), and an increase in classification accuracy (i.e., entropy).

These trends indicate that the more profiles are distinguished, the better the model fit. At the same time, the likelihood ratio tests show that there is no significant gain in model fit when comparing the twoprofile model with the three-profile model. Moreover, the three profiles in the latter model identified were by and large overlapping and therefore not clearly distinct from a theoretical point of view. As a consequence, we accepted the two-profile model as our final model to describe the latent profiles in the current study. This model did not only have reasonably high entropy (.820), but also uncovered two clearly distinct and interpretable profiles.

Table 2

Comparisons of relative model fit indices between latent profile analysis models with up to three profiles

\begin{tabular}{|c|c|c|c|c|c|c|c|c|c|}
\hline $\begin{array}{l}\text { No of } \\
\text { latent } \\
\text { profiles }\end{array}$ & $\begin{array}{l}\text { LogL } \\
\text { (Npar) }\end{array}$ & SCF & AIC & BIC & $\mathrm{aBIC}$ & Entropy & $\begin{array}{l}p \text { (VLMR- } \\
\text { LRT) }\end{array}$ & $\begin{array}{l}p(\text { LMR- } \\
\text { LRT) }\end{array}$ & $\begin{array}{l}\text { Interpret- } \\
\text { ability }\end{array}$ \\
\hline 1 & $\begin{array}{r}-5671.7 \\
(14)\end{array}$ & 1.238 & 11372 & 11435 & 11391 & 1.000 & - & - & \\
\hline 2 & $\begin{array}{r}-5101.1 \\
(24)\end{array}$ & 1.457 & 10250 & 10359 & 10283 & 0.820 & .000 & .000 & Good \\
\hline 3 & $\begin{array}{r}-4876.0 \\
(34)\end{array}$ & 1.549 & 9820 & 9974 & 9866 & 0.842 & .089 & .091 & Difficult \\
\hline
\end{tabular}

Note. LogL = Loglikelihood, Npar = number of parameters, SCF = scaling correction factor (Satorra \& Bentler, 2010), VLMR-LRT = Vuong-Lo-Mendell-Rubin likelihood ratio test, LMR-LRT = Lo-MendellRubin likelihood ratio test.

Description of the latent profiles

Based on the latent profile analysis, the respondents were distributed among two profiles as follows: 241 were classified as Profile 1 members (35\% of the 688 respondents) and 447 were grouped in Profile 2 (65\%). The differences between the mean scores of the two profiles were statistically significant for all scale scores. Pre-service teachers in Profile 2 reflect higher scores on all the different scales compared to pre-service teachers in Profile 1. The latter profile is therefore labelled as Low ICT Profile (L-ICT). In contrast, Profile 2 is labelled as High ICT Profile (H-ICT). Table 3 provides an overview of the 
descriptive statistics and the corresponding effect sizes. In order to disentangle the statistically significant differences across profiles in the seven variables and to supplement the evidence on the distinction between two profiles, we performed a one-way MANOVA and found a significant multivariate main effect of the most likely profile membership, Wilks' $\Lambda=0.41, F(7,657)=136.4, p<.001$, partial$\eta^{2}=.592$. The power to detect this main effect was 1.00. Given the significance of the overall test, the univariate main effects were examined under the Bonferroni adjustment of $p$-values in order to prevent type I errors, adjusted $p$-value $=0.05 / 7=0.007431$ (Table 3 ). These univariate effects exhibited significant differences between the two profiles in all variables with substantial effect sizes, $d=0.97$ 1.91. Besides these findings, there was evidence that the covariance matrices differed between the two profiles, Box' $M=222.2, F(28,783763.9)=7.83, p<.001$. This result needs further attention in future studies that target the identification of latent profiles on the basis of the correlations among variables.

Table 3

Mean comparisons across the two identified profiles

\begin{tabular}{lrrrr}
\hline Variables & $\begin{array}{r}\text { Latent profile } 1 \\
(N=241)\end{array}$ & $\begin{array}{r}\text { Latent profile } 2 \\
(N=447)\end{array}$ & $d$ & $95 \%$ C.I. $d$ \\
\hline SDQ & $2.13(0.92)$ & $3.02(0.92)$ & $0.97^{*}$ & {$[0.81 ; 1.14]$} \\
General ICT attitudes & $2.83(0.66)$ & $3.82(0.66)$ & $1.51^{*}$ & {$[1.33 ; 1.68]$} \\
Attitudes toward the & $3.53(0.71)$ & $4.26(0.71)$ & $1.03^{*}$ & {$[0.86 ; 1.19]$} \\
educational ICT use & $2.64(0.77)$ & $3.77(0.77)$ & $1.47^{*}$ & {$[1.29 ; 1.64]$} \\
Ease of ICT use & $2.75(0.62)$ & $3.68(0.62)$ & $1.31^{*}$ & {$[1.13 ; 1.48]$} \\
ICT self-efficacy & $2.14(0.47)$ & $2.91(0.47)$ & $1.65^{*}$ & {$[1.47 ; 1.83]$} \\
TPACK & $1.85(0.53)$ & $2.87(0.53)$ & $1.91^{*}$ & {$[1.72 ; 2.10]$} \\
Technological & & & & \\
knowledge (TK) & & & & \\
\hline
\end{tabular}

Note. $d$ = Effect size Cohen's $d$ with its 95\% confidence interval (C.I.).

\# This variable contained the TPACK dimensions TPCK, TPK, and TCK. $* p<.05 / 7=.00743$.

Figure 2 provides a graphical representation of the two profiles' means and their SEMs of the seven classification measures.

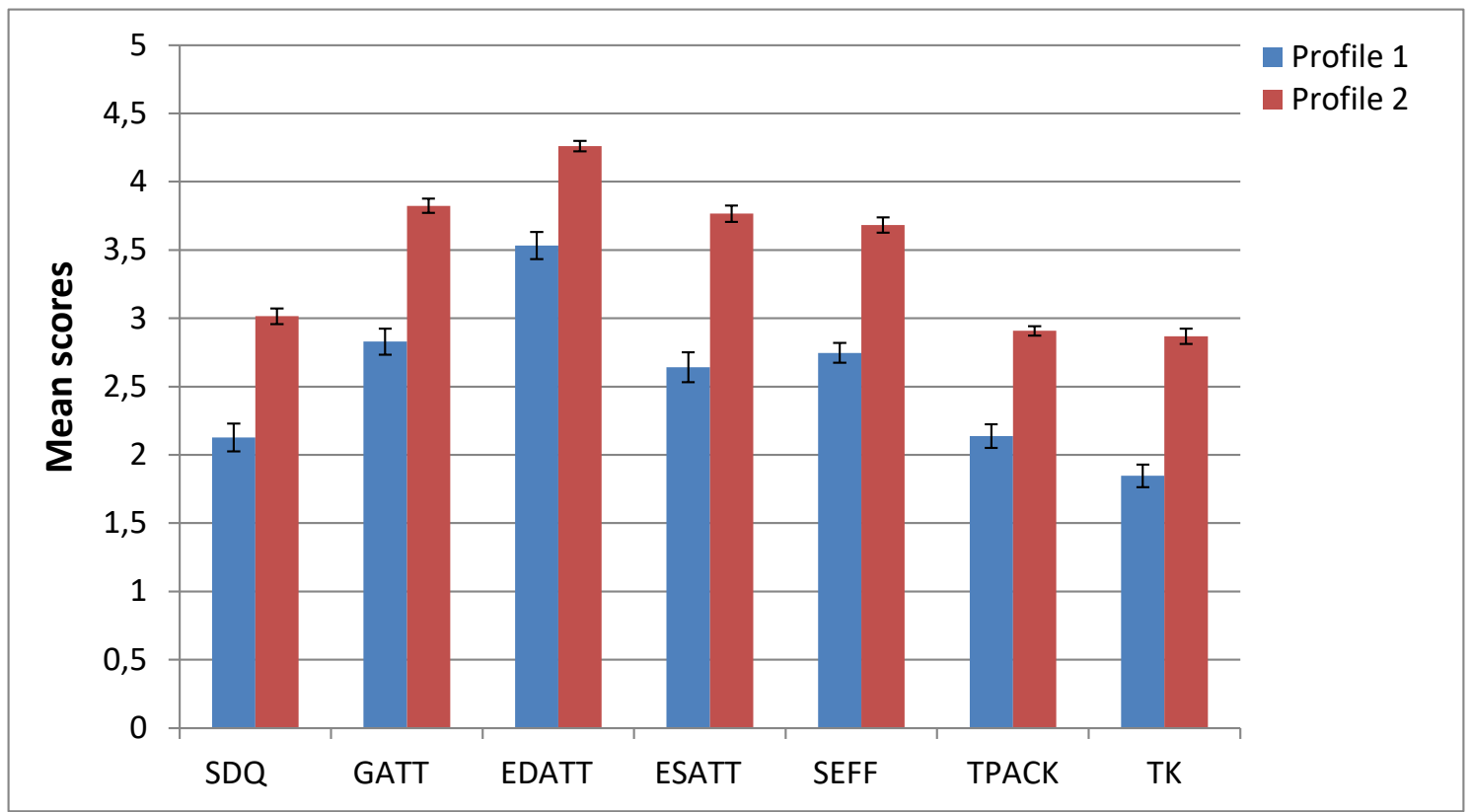

Figure 2. Mean scores of the two profiles on the selected scales

Note. SDQ = Synthesis of Qualitative Data (Strategies to prepare pre-service teachers), GATT = General ICT attitudes, EDATT = Attitudes toward the educational use of ICT, ESATT = Ease of ICT use, SEFF = ICT self-efficacy, TPACK = Technological-pedagogical and content-related TPACK dimensions (i.e., TPCK, TPK, TCK), TK = Technological knowledge. 
Pre-service teacher' age did not significantly predict profile membership $(B=0.009$, $S E=0.014$, $p=0.539, O R=1.009)$; moreover, women were more likely to be members of the first profile $(B=0.559$, $S E=0.239, p=0.015, O R=1.748)$.

\section{Discussion and conclusion}

The main aim of this study was to identify profiles of pre-service teachers in order to explore their readiness to integrate technology in teaching and learning activities. Two profiles were identified based on their TPACK, other individual ICT-related characteristics, and the perceived support provided by their teacher training institution: (1) the high educational ICT profile (H-ICT) and (2) the low educational ICT profile (L-ICT). In both profiles, all individual characteristics (e.g., general ICT attitudes, attitudes toward the use of ICT in education, self-efficacy, and their TPACK) were positively correlated. This finding is in line with previous research that suggests that general and domain specific attitudes toward the use of ICT in education are closely related (cf. Agyei \& Voogt, 2015). Another general finding is that (pre-service) teachers adopting more positive ICT attitudes were more likely to report positive attitudes toward ICT in education (see also Tondeur, Van de Velde, Vermeersch, \& Van Houtte, 2017). Interestingly, pre-service teachers' ICT self-efficacy, ease of use, and their TPACK go together within both profiles.

Looking at the two profiles it is clear that some pre-service teachers are intrinsically motivated to use ICT in their educational practice, while others do not share this affinity (e.g., Teo \& Milutinovic, 2015). For this reason, many researchers placed the individual teacher at the centre of educational change processes (Stoll, 1999). The results of this study indicate a positive association between TPACK and SQD. Preservice teachers in a profile with relatively positive attitudes, self-efficacy and TPACK also report higher scores on the perceived support provided by their teacher training institution. As a consequence, understanding of pre-service teachers' ICT profile is a crucial factor in supporting pre-service teachers for ICT integration in education. TTIs play an important role in providing pre-service teachers of both profiles with opportunities to learn and build their TPACK. Clearly, these pre-service teachers in L-ICT also reflect less perceived support from their TTI. Consequently, measuring pre-service teachers' ICT profile can be seen as an evaluation whereby TTIs can adjust the support needed to prepare future teachers for meaningful ICT integration in education. Moreover, from these results - although the direction of causality cannot be described - our study shows that TTIs matter for pre-service teachers' overall ICT profiles.

The discussion on the ways in which pre-service teachers can be better prepared for TPACK should also be seen as part of the development of the entire teacher education programme as demonstrated in the SQD model (Tondeur, van Braak, Siddiq et al., 2016). Technology needs to be infused as a systemic and systematic process throughout the entire teacher training programme. Several authors also argued that pre-service teachers need to work in collaborative groups and actively engage in the research on and design of tangible, meaningful ICT-related curriculum materials as end products of the learning process (Lee \& Lee, 2014; Mouza et al., 2014). Many studies demonstrated that group work might mitigate feelings of insecurity of pre-service teachers in the Low ICT profile when they need to design technology-related curriculum materials (Angeli \& Valanides, 2009; Tearle \& Golder, 2008). In this respect, the findings of the current study can be used to make the composition of the groups based on the profiles, because this can have an influence on how positive the experience was felt to be (Jang, 2008). Their study also suggests that there may be some benefits in changing the composition of working groups over the course. Finally, research on TPACK (e.g., Koehler \& Mishra, 2009) suggests that the opportunity to design technology-enhanced curriculum materials by design teams is a promising strategy for teachers. Through collaboration pre-service teachers can share their attitudes and abilities with one another.

\section{Limitations and recommendations for future research}

The added value of the current study lies in the richer account of how TPACK and a typical set of determinants of ICT integration can be associated within pre-service teachers' profile. A better insight into their educational ICT profile is needed to guide future teachers in the development of TPACK and educational technology use. TTIs should closely consider their pre-service teachers, acknowledge their ICT profiles and take their background into consideration when preparing them for the twenty-first century learning environments with new technologies. 
Although the present study provided an in-depth exploration of the ICT profiles of pre-service teachers, the study also reflects some shortcomings. Apart from the added value of seeking an evaluation of the TPACK profile outside the Flemish context or for in-service teachers, pre-service teachers are probably not only influenced by ICT-related factors. Pre-service teachers interpret innovations according to their pedagogical beliefs (Tondeur, van Braak, Ertmer et al. 2016; Ertmer, 2005; Prestridge, 2012). In other words, they accept innovations that are in accordance with their personal conceptions of teaching and learning. It is therefore necessary to understand how pre-service teachers think about good education. From a methodological point of view, any procedure that is aimed at identifying profiles or clusters of individuals on the basis of selected variables suffers from sample specificity to a certain extent (Morin \& Marsh, 2015). We would therefore like to stimulate replication studies of our approach in order to put to test its robustness across different samples of pre-service teachers. Moreover, although it is desirable to identify more than two profiles based on the considerable number of ICT-related variables, greater complexity - as it is manifested by larger numbers of latent profiles - often contradicts the interpretability and practical relevance of profiles. Consequently, identifying educational approaches to support preservice teachers' technology integration and address their ICT-related profiles at the same time, becomes a substantial challenge. From a statistical point of view, however, models with more profiles may capture the complexity of the data to a better extent than models with fewer profiles, as indicated by an improvement in model fit indices (Marsh et al., 2009). In their recent review article, Harring and Hodis (2016) addressed this issue and argued that "the final decision [on the number of profiles] should not weight heavier this [statistical] type of information than theoretical and substantive considerations" (p. 361), and "important are the insights of the practitioner or substantive researcher who can marry the information garnered from the analysis with what seems theoretically defensible” (p. 365). Following this argumentation, we conclude that statistical preference and interpretability need to be balanced when disentangling profiles on the basis of substantively relevant variables.

The static nature of the data, gathered to develop the ICT profiles, also pose difficulties to grasp the dynamic and evolving nature of preparing future teachers for educational technology use. Future research should therefore adopt an iterative approach in developing the teachers' profiles and comparisons should also be made over time. It would be interesting to verify whether TTI change the profiles according to different stages of development. Future research should therefore adopt an iterative approach in developing the ICT profiles of (pre-service) teachers. Finally, the TPACK profiles could be used as a determinant to measure the extent to which pre-service teachers actually use ICT in their educational practice. These results can provide a good stepping stone to better prepare pre-service teachers for technology integration in education.

\section{References}

Abbitt, J. T. (2011). An investigation of the relationship between self-efficacy beliefs about technology integration and technological pedagogical content knowledge (TPACK) among preservice teachers. Journal of Digital Learning in Teacher Education, 27(4), 134-143. https://doi.org/10.1080/21532974.2011.10784670

Agyei, D. D., \& Voogt, J. M. (2014). Examining factors affecting beginning teachers' transfer of learning of ICT-enhanced learning activities in their teaching practice. Australasian Journal of Educational Technology, 30(1), 92-105. https://doi.org/10.14742/ajet.499

Agyei, D. D., \& Voogt, J. M. (2015). Pre-service teachers' TPACK competencies for spreadsheet integration: insights from a mathematics-specific instructional technology course. Technology, Pedagogy and Education, 24(5), 605-625. https://doi.org/10.1080/1475939X.2015.1096822

Angeli, C., \& Valanides, N. (2009). Epistemological and methodological issues for the conceptualization, development, and assessment of ICT-TPCK: Advances in technological pedagogical content knowledge (TPCK). Computers \& Education, 52(1), 154-168. https://doi.org/10.1016/j.compedu.2008.07.006

Aslan, A., \& Zhu, C. (2016). Influencing factors and integration of ICT into teaching practices of preservice and starting teachers. International Journal of Research in Education and Science, 2(2), 359370. https://doi.org/10.21890/ijres.81048

Banas, J. R., \& York, C. S. (2014). Authentic learning exercises as a means to influence preservice teachers' technology integration self-efficacy and intentions to integrate technology. Australasian Journal of Educational Technology, 30(6), 728-746. https://doi.org/10.14742/ajet.362 
Bergman, L. R., \& Magnusson, D. (1997). A person-oriented approach in research on developmental psychopathology. Development and Psychopathology, 9(2), 291-319. https://doi.org/10.1017/S095457949700206X

Bergman, L. R., von Eye, A., \& Magnusson, D. (2006). Person-oriented research strategies in developmental psychopathology. In D. Cicchetti \& D. J. Cohen (Eds.), Developmental psychopathology: Theory and method (2nd ed., Vol. 1, pp. 850-888). New York, NY: John Wiley \& Sons.

Bergman, L. R., \& Wångby, M. (2014). The person-oriented approach: A short theoretical and practical guide. Eesti Haridusteaduste Ajakiri, 2(1), 29-49. https://doi.org/10.12697/eha.2014.2.1.02b

Berlin, K. S., Williams, N. A., \& Parra, G. R. (2014). An introduction to latent variable mixture modeling (part 1): overview and cross-sectional latent class and latent profile analyses. Journal of Pediatric Psychology, 39(2), 174-187. https://doi.org/10.1093/jpepsy/jst084

Compeau, D. R., \& Higgins, C. A. (1995). Computer self-efficacy: Development of a measure and initial test. MIS Quarterly, 19(2), 189-211. https://doi.org/10.2307/249688

Enders, C. K. (2010). Applied missing data analysis. New York, NY: Guilford Press.

Ertmer, P. A. (2005). Teacher pedagogical beliefs: The final frontier in our quest for technology integration? Educational Technology Research and Development, 53(4), 25-39. https://doi.org/10.1007/BF02504683

Evers, M., Sinnaeve, I., Clarebout, G., van Braak, J., \& Elen, J. (2009). Monitoring ICT in het Vlaamse onderwijs.

Fisser, P., Voogt, J., van Braak, J., \& Tondeur, J. (2015). Measuring and assessing TPACK (technological, pedagogical content knowledge). In J. M. Spector (Ed.), The SAGE encyclopedia of educational technology (Vol. 2, pp. 490-493). Thousand Oaks, CA: Sage Publications.

Fullan, M. (2001). The new meaning of educational change (3rd ed.). London: RoutledgeFalmer.

Harring, J. R., \& Hodis, F. A. (2016). Mixture modeling: Applications in educational psychology. Educational Psychologist, 51(3-4), 354-367. https://doi.org/10.1080/00461520.2016.1207176

Holland, D. D., \& Piper, R. T. (2016). A technology integration education (tie) model for millennial preservice teachers: exploring the canonical correlation relationships among attitudes, subjective norms, perceived behavioral controls, motivation, and technological, pedagogical, and content knowledge (TPACK) competencies. Journal of Research on Technology in Education, 48(3), 212226. https://doi.org/10.1080/15391523.2016.1172448

Jang, S.J. (2008). Innovations in science teacher education: Effects of integrating technology and teamteaching strategies. Computers \& Education, 51(2), 646-659. https://doi.org/10.1016/j.compedu.2007.07.001

Kaufman, K. (2015). Information communication technology: Challenges \& some prospects from preservice education to the classroom. Mid-Atlantic Education Review, 2(1), 1-11.

Kavanoz, S., Yuksel, H., \& Ozcan. E. (2015) Pre-service teachers' self-efficacy perceptions on WEB pedagogical content knowledge. Computers \& Education, 85, 94-101. https://doi.org/10.1016/j.compedu.2015.02.005

Kay, R. (2006). Evaluating strategies used to incorporate technology into pre-service education: A review of the literature. Journal of Research on Technology in Education, 38(4), 383-408. https://doi.org/10.1080/15391523.2006.10782466

Koehler, M., \& Mishra, P. (2009). What is technological pedagogical content knowledge (TPACK)? Contemporary Issues in Technology and Teacher Education, 9(1), 60-70.

Laursen, B., \& Hoff, E. (2006). Person-centered and variable-centered approaches to longitudinal data. Merrill-Palmer Quarterly, 52(3), 377-389. https://doi.org/10.1353/mpq.2006.0029

Lee, Y., \& Lee, J. (2014). Enhancing pre-service teachers' self-efficacy beliefs for technology integration through lesson planning practice. Computers \& Education, 73, 121-128. https://doi.org/10.1016/j.compedu.2014.01.001

Liu, S. H. (2016). Teacher education programs, field-based practicums, and psychological factors of the implementation of technology by pre-service teachers. Australasian Journal of Educational Technology, 32(3), 65-79. https://doi.org/10.14742/ajet.2139

Lo, Y., Mendell, N. R., \& Rubin, D. B. (2001). Testing the number of components in a normal mixture. Biometrika, 88(3), 767-778. https://doi.org/10.1093/biomet/88.3.767

Magnusson, D. (1998). The logic and implications of a person-oriented approach. In R. B. Cairns, L. R. Bergman, \& J. Kagan (Eds.), Methods and models for studying the individual (pp. 33-63). Thousand Oaks, CA: Sage. 
Marsh, H. W., Lüdtke, O., Trautwein, U., \& Morin, A. J. S. (2009). Classical latent profile analysis of academic self-concept dimensions: Synergy of person- and variable-centered approaches to theoretical models of self-concept. Structural Equation Modeling: A Multidisciplinary Journal, 16(2), 191-225. https://doi.org/10.1080/10705510902751010

Masyn, K. E. (2013). Latent class analysis and finite mixture modeling. In T. D. Little (Ed.), The Oxford handbook of quantitative methods inpPsychology (Vol. 2, pp. 551-611). Oxford: Oxford University Press. https://doi.org/10.1093/oxfordhb/9780199934898.013.0025

Morin, A. J. S., \& Marsh, H. W. (2015). Disentangling shape from level effects in person-centered analyses: An illustration based on university teachers' multidimensional profiles of effectiveness. Structural Equation Modeling: A Multidisciplinary Journal, 22(1), 39-59. https://doi.org/10.1080/10705511.2014.919825

Morin, A. J. S., Morizot, J., Boudrias, J. S., \& Madore, I. (2011). A multifoci person-centered perspective on workplace affective commitment: A latent profile/factor mixture analysis. Organizational Research Methods, 14(1), 58-90. https://doi.org/10.1177/1094428109356476

Mouza, C., Karchmer-Klein, R., Nandakumar, R., Ozden, S. Y., \& Hu, L. (2014). Investigating the impact of an integrated approach to the development of preservice teachers' technological pedagogical content knowledge (TPACK). Computers \& Education, 71, 206-221. https://doi.org/10.1016/j.compedu.2013.09.020

Muthén, B., \& Muthén, L. (1998-2015). Mplus (Version 7.3). Los Angeles, CA: Muthén \& Muthén.

Niess, M. L. (2015). Transforming teachers' knowledge: Learning trajectories for advancing teacher education for teaching with technology. In Technological pedagogical content knowledge (pp. 19-37). Boston, MA: Springer.

Nylund, K. L., Asparouhov, T., \& Muthén, B. O. (2007). Deciding on the number of classes in latent class analysis and growth mixture modeling: A Monte Carlo simulation study. Structural Equation Modeling: A Multidisciplinary Journal, 14(4), 535-569. https://doi.org/10.1080/10705510701575396

Ottenbreit-Leftwich, A. T., Ertmer, P. A., \& Tondeur, J. (2015). Interpretation of research on technology integration in teacher education in the USA: Preparation and current practices. In H. Fives, \& M. G. Gill (Eds.) International handbook of interpretation in educational research (pp. 1239-1262). Netherlands: Springer. https://doi.org/10.1007/978-94-017-9282-0_61

Ottenbreit-Leftwich, A. T., Glazewski, K., Newby, T., \& Ertmer, P. (2010). Teacher value beliefs associated with using technology: Addressing professional and student needs. Computers \& Education, 55(3), 1321-1335. https://doi.org/10.1016/j.compedu.2010.06.002

Pastor, D. A., Barron, K. E., Miller, B. J., \& Davis, S. L. (2007). A latent profile analysis of college students' achievement goal orientation. Contemporary Educational Psychology, 32(1), 8-47. https://doi.org/10.1016/j.cedpsych.2006.10.003

Polly, D., Mims, C., Shepherd, C., \& Inan, F. (2010). Evidence of impact: transforming teacher education with preparing tomorrow's teachers to teach with technology (PT3) grants. Teaching and Teacher Education, 26,(4), 863-870. https://doi.org/10.1016/j.tate.2009.10.024

Prestridge, S. (2012). The beliefs behind the teacher that influences their ICT practices. Computers \& Education, 58(1), 449-458. https://doi.org/10.1016/j.compedu.2011.08.028

Pynoo, B., Devolder, P., Tondeur, J., van Braak, J., Duyck, W., \& Duyck, P. (2011). Predicting secondary school teachers' acceptance and use of a digital learning environment: A cross-sectional study. Computers in Human behavior, 27(1), 568-575. https://doi.org/10.1016/j.chb.2010.10.005

Reinecke, J. (2006). Longitudinal analysis of adolescents' deviant and delinquent behavior: Applications of latent class growth curves and growth mixture models. Methodology, 2(3), 100-112. https://doi.org/10.1027/1614-1881.2.3.100

Sang, G., Tondeur, J., \& Chai, C.S. (2014). Validation and profile of Chinese pre-service teachers' technological pedagogical content knowledge scale. Asia-Pacific Journal of Teacher Education, 1(17), 49-65.

Sang, G., Valcke, M., van Braak, J., \& Tondeur, J. (2010). Student teachers' thinking processes and ICT integration: Predictors of prospective teaching behaviors with educational technology. Computers \& Education, 54(1), 103-112. https://doi.org/10.1016/j.compedu.2009.07.010

Sang, G., Valcke, M., van Braak, J., Tondeur, J., Chang, Z. \& Yu, K. (2012). Challenging science teachers' beliefs and practices through a video-case-based intervention in China's primary schools. Asia-Pacific Journal of Teacher Education, 40(4), 363-378. https://doi.org/10.1080/1359866X.2012.724655

Satorra, A., \& Bentler, P. (2010). Ensuring positiveness of the scaled difference chi-square test statistic. Psychometrika, 75(2), 243-248. https://doi.org/10.1007/s11336-009-9135-y 
Scherer, R., Siddiq, F., \& Teo, T. (2015). Becoming more specific: Measuring and modeling teachers' perceived usefulness of ICT in the context of teaching and learning. Computers \& Education, 88, 202-214. https://doi.org/10.1016/j.compedu.2015.05.005

Scherer, R., Siddiq, F., \& Tondeur, J. (In press). On the quest for validity: Testing the factor structure and measurement invariance of the technology-dimensions in the technological, pedagogical, and content knowledge (TPACK) model. Computers \& Education, 112,1-17.. https://doi.org/10.1016/j.compedu.2017.04.012

Schmidt, D. A., Baran, E., Thompson, A. D., Mishra, P., Koehler, M. J., \& Shin, T. S. (2009). Technological pedagogical content knowledge (TPACK) the development and validation of an assessment instrument for preservice teachers. Journal of Research on Technology in Education, 42(2), 123-149. https://doi.org/10.1080/15391523.2009.10782544

Semiz, K., \& Ince, M. L. (2012). Pre-service physical education teachers' technological pedagogical content knowledge, technology integration self-efficacy and instructional technology outcome expectations. Australasian Journal of Educational Technology, 28(6), 1248-1265. https://doi.org/10.14742/ajet.800

Siddiq, F., Scherer, R., \& Tondeur, J. (2016). Teachers' emphasis on developing students' digital information and communication skills (TEDDICS): A new construct in 21st century education. Computers \& Education, 92, 1-14. https://doi.org/10.1016/j.compedu.2015.10.006

Spector, J. M. (2010). An overview of progress and problems in educational technology. Interactive Educational Multimedia, 1, 27-37.

Stoll, L. (1999). Realising our potential: Understanding and developing capacity for lasting improvement. School Effectiveness and School Improvement, 10(4), 503-532.

Tearle, P., \& Golder, G. (2008). The use of ICT in the teaching and learning of physical education in compulsory education: how do we prepare the workforce of the future European. Journal of Teacher Education, 31(1), 55-72. https://doi.org/10.1080/02619760701845016

Tein, J. Y., Coxe, S., \& Cham, H. (2013). Statistical power to detect the correct number of classes in latent profile analysis. Structural Equation Modeling: A Multidisciplinary Journal, 20(4), 640-657. https://doi.org/10.1080/10705511.2013.824781

Teo, T. (2008). Pre-service teachers' attitudes towards computer use: A Singapore survey. Australasian Journal of Educational Technology, 24(4), 413-424. https://doi.org/10.14742/ajet.1201

Teo, T., \& Milutinovic, V. (2015). Modelling the intention to use technology for teaching mathematics among pre-service teachers in Serbia. Australasian Journal of Educational Technology, 31(4), 363380. https://doi.org/10.14742/ajet.1668

Tondeur, J., Aesaert, K., van Braak, J., Pynoo, B., Freyman, N., \& Erstadt, O. (2017). Developing a validated instrument to measure pre-service teachers' ICT competencies: Meeting the demands of the 21st-century. British Journal of Educational Technology, 48(2), 462-472. https://doi.org/10.1111/bjet.12380

Tondeur, J., Pareja Roblin N., van Braak, J., Fisser, P., \& Voogt, J. (2013). Technological pedagogical content knowledge in teacher education: In search of a new curriculum. Educational Studies, 39(2), 239-243. https://doi.org/10.1080/03055698.2012.713548

Tondeur, J., Pareja Roblin, N., van Braak, J., Voogt, J., \& Prestridge, S. (2017). Preparing beginning teachers for technology integration in education: ready for take-off? Technology, Pedagogy and Education, 26(2), 157-177.

Tondeur, J., van Braak, J., Ertmer, P. A., \& Ottenbreit-Leftwich, A. (2016). Understanding the relationship between teachers' pedagogical beliefs and technology use in education: a systematic review of qualitative evidence. Educational Technology Research and Development, 65(3), 555-575.

Tondeur, J., van Braak, J., Sang, G., Voogt, J., Fisser, P., \& Ottenbreit-Leftwich, A. (2012). Preparing pre-service teachers to integrate technology in education: A synthesis of qualitative evidence. Computers \& Education, 59(1), 134-144. https://doi.org/10.1016/j.compedu.2011.10.009

Tondeur, J., van Braak, J., Siddiq, F., \& Scherer, R. (2016). Time for a new approach to prepare future teachers for educational technology use: Its meaning and measurement. Computers \& Education, 94, 134-150. https://doi.org/10.1016/j.compedu.2015.11.009

Tondeur, J., Van de Velde, S., Vermeersch, H., \& Van Houtte, M. (2017). Gender differences in the ICT profile of university students: A quantitative analysis. Journal of Diversity and Gender Studies, 3(1). Retrieved from http://www.digest.ugent.be/abstracttondeuretal

Valtonen, T., Kukkonen, J., Kontkanen, S., Sormunen, K., Dillon, P., \& Sointu, E. (2015). The impact of authentic learning experiences with ICT on pre-service teachers' intentions to use ICT for teaching and learning. Computers \& Education, 81, 49-58. https://doi.org/10.1016/j.compedu.2014.09.008 
Venkatesh, V., Jedwab, J., Rabah, J., Thomas, T., Varela, W., \& Alexander, K. (2013). From disconnected to connected: Insights into the future of distance education and Web 2.0 tools in higher education. Revue internationale des technologies en pédagogie universitaire/International Journal of Technologies in Higher Education, 10(3), 6-13. https://doi.org/10.7202/1035575ar

Voogt, J., Fisser, P., Pareja, N., Tondeur, J., \& van Braak, J. (2013). Technological Pedagogical Content Knowledge - a review of the literature. Journal of Computer Assisted Learning, 29(2), 190-121. https://doi.org/10.1111/j.1365-2729.2012.00487.x

Corresponding author: Jo Tondeur, Jo.Tondeur@vub.be

Australasian Journal of Educational Technology (c) 2017.

Please cite as: Tondeur, J., Scherer, R., Siddiq, F., \& Baran, E. (2017). A comprehensive investigation of TPACK within pre-service teachers’ ICT profiles: Mind the gap! Australasian Journal of Educational Technology, 33(3), 46-60. https://doi.org/10.14742/ajet.3504 


\section{Appendix A}

Descriptive statistics and reliabilities of the T-dimensions measure (English translation)

\begin{tabular}{|c|c|c|c|}
\hline Item & Wording & $M$ & $S D$ \\
\hline \multicolumn{4}{|c|}{ Technological content knowledge (TCK) } \\
\hline TCK1 & $\begin{array}{l}\text { I am aware of ICT applications that I can use to give students insight into } \\
\text { the subject I teach. }\end{array}$ & 2.47 & 0.86 \\
\hline TCK2 & I am aware of ICT applications to support the subject I teach. & 2.49 & 0.86 \\
\hline TCK3 & I can choose ICT applications that support lessons a subject domain. & 2.74 & 0.75 \\
\hline TCK4 & $\begin{array}{l}\text { I know how to use ICT applications to present concepts from a discipline } \\
\text { in a different way to my students. }\end{array}$ & 2.67 & 0.78 \\
\hline \multicolumn{4}{|c|}{ Technological pedagogical knowledge (TPK) } \\
\hline TPK1 & I can choose technologies that enhance students’ learning for a lesson. & 2.67 & 0.76 \\
\hline TPK2 & $\begin{array}{l}\text { I can choose technologies that enhance the teaching approaches for a } \\
\text { lesson. }\end{array}$ & 2.77 & 0.72 \\
\hline TPK3 & $\begin{array}{l}\text { I can adapt the use of the technologies that I am learning about to } \\
\text { different teaching activities. }\end{array}$ & 2.67 & 0.76 \\
\hline TPK4 & I am thinking critically about how to use technology in my classroom. & 2.77 & 0.73 \\
\hline TPK5 & $\begin{array}{l}\text { My teacher education program has caused me to think more deeply about } \\
\text { how technology could influence the teaching approaches I use in my } \\
\text { classroom. }\end{array}$ & 2.51 & 0.93 \\
\hline \multicolumn{4}{|c|}{ Technological pedagogical content knowledge (TPCK) } \\
\hline TPCK1 & $\begin{array}{l}\text { I can teach lessons that appropriately combine technologies, literacy, and } \\
\text { teaching approaches. }\end{array}$ & 2.68 & 0.78 \\
\hline TPCK2 & $\begin{array}{l}\text { I can use strategies that I have learned (in my teacher education program) } \\
\text { to combine ICT, content, and pedagogy. }\end{array}$ & 2.58 & 0.81 \\
\hline TPCK3 & I can choose ICT applications that enhance what and how I teach. & 2.70 & 0.71 \\
\hline TPCK4 & $\begin{array}{l}\text { I can choose ICT applications for a subject domain that enhance what and } \\
\text { how I teach. }\end{array}$ & 2.66 & 0.76 \\
\hline TPCK5 & $\begin{array}{l}\text { I can give lessons about a subject area that appropriately integrate ICT, } \\
\text { content, and teaching approaches. }\end{array}$ & 2.61 & 0.80 \\
\hline \multicolumn{4}{|c|}{ Technological knowledge (TK) } \\
\hline TK1 & I know how to solve my own technical problems. & 2.47 & 0.96 \\
\hline TK2 & I can learn technology easily. & 2.66 & 0.91 \\
\hline TK3 & I keep up with important new technologies. & 2.18 & 0.99 \\
\hline TK4 & I frequently play around with the technology. & 2.58 & 0.92 \\
\hline TK5 & I know about a lot of different technologies. & 2.47 & 0.95 \\
\hline TK6 & I have the technical skills I need to use technology. & 2.72 & 0.84 \\
\hline TK7 & I have had sufficient opportunities to work with different technologies. & 2.51 & 0.90 \\
\hline
\end{tabular}

